\title{
Phenotypic and Genotypic Characterization of Methicillin, Vancomycin, and Erythromycin-resistant Staphylococcus aureus Isolated from Milk and Dairy Products
}

\author{
Shimaa Tawfeeq Omara", Ashraf Samir Hakim, and Magdy Ali Bakry \\ Department of Microbiology and Immunology, National Research Centre, 33 Bohouth St. Dokki, Affiliation I.D. 60014618, Postal Code 12311, Giza, Egypt \\ *Corresponding author`s Email: shimaaomara2112@gmail.com; (DORCiD: 0000-0002-3521-9665
}

\begin{abstract}
Detailed information on the resistance patterns of Staphylococcus aureus (S. aureus) in milk and cheese is strongly required to facilitate risk assessment analysis in case of food poisoning context and to improve therapeutic approaches used in dairy farms. The present study aimed to perform phenotypic and genotypic antimicrobial characterizations of methicillin, vancomycin, and erythromycin-resistant $S$. aureus isolated from milk and dairy products through screening $m e c A$, vanA, and ermC using molecular PCR amplification technology. Moreover, the association between each genotypic and its related antibiotic resistance phenotypic features within the isolated $S$. aureus strains were analyzed. Moreover, the current study aimed to study MRSA's ability to form biofilms. Out of 226 milk and dairy product samples collected from different retailers in Giza Governorate, $69.5 \%$ of the samples were positive for the presence of $S$. aureus. The isolation rate of $S$. aureus strains from cattle milk, sheep milk, white cheese, flamenco, and mesh samples were $79.7 \%, 76.5 \%, 56.0 \%, 40.0 \%$, and $94.7 \%$, respectively. Multidrugresistant $S$. aureus (MDR) was detected in $51 \%$ of all isolated $S$. aureus strains. All tested S. aureus strains were sensitive to trimethoprim-sulfamethoxazole, linezolid, ciprofloxacin, and gentamycin. However, their resistance rates against penicillin, oxacillin, vancomycin, erythromycin, tetracycline, clindamycin and chloramphenicol were $62.4 \%, 65.0 \%, 44.6 \%, 45.9 \%, 21.0 \%, 14.0 \%$, and $2.5 \%$, respectively. Of the isolated S. aureus strains, $72.6 \%$, $40.1 \%$, and $48.4 \%$ were carriers for mecA, vanA, and ermC genes and the amplified products were at 310, 1030, and 295 bp, respectively. Methicillin-resistant $S$. aureus isolates were detected in $47.1 \%$ of all isolated $S$. aureus strains. The results indicated that $35.0 \%$ of the tested $S$. aureus strains were genotypic vanA gene carriers and phenotypic resistant to vancomycin representing vancomycin-resistant $S$. aureus strains. Moreover, $42.7 \%$ of all isolated $S$. aureus strains were carriers for ermC gene and were phenotypic resistant to erythromycin representing erythromycin-resistant $S$. aureus. The presence of mecA, vanA, and ermC genes in $S$. aureus was statistically associated with their related phenotypic resistance patterns against both penicillin and oxacillin, vancomycin, and erythromycin, respectively. Moreover, along with an increase in the frequency of mecA, vanA, and erm $C$ genes, their phenotypic antibiotic resistance patterns sharply increased with an odd ratio $>1$. Of MRSA isolates, $6.8 \%$ indicated weak biofilm-formation ability, while $93.2 \%$ exhibit no biofilm-forming ability.
\end{abstract}

Keywords: Erythromycin-Resistant, mecA, Methicillin-Resistant, Staphylococcus aureus, Vancomycin-Resistant.

\section{INTRODUCTION}

Staphylococcus aureus is a facultative anaerobic gram-positive bacterium, and it is considered one of the most predominant causes of worldwide foodborne poisoning (Cai et al., 2021). Consumption of milk and dairy products contaminated with $S$. aureus represents a public-health risk. Dairy products can provide favorable conditions for $S$. aureus propagation particularly if they are made from raw milk (Zayda et al., 2020). Contamination of dairy products by S. aureus can occur through the infected animal's mammary glands, mucosal surfaces, and skin. This contamination could also occur through contaminated milking equipment, workers' or milkers' hands, and also through the contaminated environment (Spanu et al., 2012).

Staphylococcus aureus bacterium has a strong ability to resist a wide range of antimicrobial agents. Multidrugresistant $S$. aureus is a worldwide alarming challenge for public health as it is associated with high morbidity and mortality. The use of penicillin and methicillin in the mid- $20^{\text {th }}$ century demonstrated adequacy against $S$. aureus. However, S. aureus rapidly acquired resistance against these antibiotics through the production of exopolysaccharides, beta-lactamase, or penicillinase, and also due to harboring different virulence genes coding for antibiotic resistance (Rola et al., 2015) with induction of a new high drug-resistant phenotypic S. aureus (Cai et al., 2021). One of the most challenged antibiotic resistance S. aureus is methicillin-resistant S. aureus (MRSA) which has been spread worldwide and become a life-threatening infection associated with bacteremia, osteomyelitis, pyomyositis, or necrotizing pneumonia (Zayda et al., 2020). Methicillin-resistant S. aureus has been reported in milk and dairy products globally (Cai et al., 2021). Rapid and accurate detection of multidrug-resistant S. aureus using molecular techniques as PCR for the detection of genes related to resistance against different antibiotics has long been known as a confirmed effective 
diagnostic and useful method to prosper in infection control policy and antimicrobial therapy effectiveness (Zayda et al., 2020). On the other hand, S. aureus can form biofilms on different surfaces. Biofilm formation in S. aureus can increase antibiotic resistance criteria and the difficulty of sanitation processes (Angelidis et al., 2020).

The present study aimed to perform phenotypic and genotypic antimicrobial characterizations of methicillin, vancomycin, and erythromycin-resistant $S$. aureus isolated from milk and dairy products through screening of $m e c A$, vanA, and ermC using molecular PCR amplification technology. The current study aimed also to analyze the association between each genotypic and its related antibiotic resistance phenotypic features within the isolated $S$. aureus strains. Moreover, the current study aimed to study MRSA's ability to form biofilms. As far as the researchers are concerned, this study can be one of the first studies on the comparison between phenotypic and genotypic characterizations of methicillin, vancomycin, and erythromycin-resistant S. aureus isolated from milk and dairy products in Egypt, in addition to studying MRSA's ability to form biofilms.

\section{MATERIALS AND METHODS}

\section{Ethical approval}

The present study does not include any in-vivo experiments on living animals.

\section{Sampling}

A total of 226 samples including 64 cattle milk, 34 sheep milk, 50 white cheese, 40 flamenco, and 38 mesh (mesh is the name of a traditional Egyptian cheese that is made by fermenting salty cheese for several months or years) samples were collected from different retailers in Giza Governorate. The samples were collected and transferred in an insulated icebox to the department of Microbiology and Immunology, Veterinary Division, National Research Centre, Cairo, Giza, Egypt, where they were investigated immediately for the presence of S. aureus.

\section{Culture of Staphylococcus aureus}

Isolation and identification of $S$. aureus from milk and dairy products were performed as described by Omara et al. (2016).

\section{Phenotypic antibiotic resistance profile of the isolated Staphylococcus aureus}

Antimicrobial resistance profiles of $S$. aureus strains were achieved by Kirby Bauer disk diffusion method based on the National Committee for Clinical Laboratory Standards (CLSI, 2013). This experiment was done using muller hinton agar (Oxoid, UK) and the following antimicrobial impregnated disks (Oxoid, UK), including erythromycin (15 $\mu \mathrm{g})$, clindamycin $(15 \mu \mathrm{g})$, oxacillin $(1 \mu \mathrm{g})$, penicillin $\mathrm{G}(10 \mathrm{IU})$, trimethoprim-sulfamethoxazole $(25 \mu \mathrm{g})$, linezolid (30 $\mu \mathrm{g})$, tetracycline $(30 \mu \mathrm{g})$, vancomycin $(30 \mu \mathrm{g})$, rifampin $(5 \mu \mathrm{g})$, chloramphenicol $(30 \mu \mathrm{g})$, ciprofloxacin $(30 \mu \mathrm{g})$, and gentamycin $(10 \mu \mathrm{g})$. After inoculation of the antimicrobial impregnated disks in the cultured muller hinton agar plates, the plates were then incubated overnight at $37^{\circ} \mathrm{C}$ and the zone sizes of inhibition were measured in millimeters and interpreted according to CLSI (2013) guidelines.

\section{Genotypic antibiotic resistance features \\ Genomic DNA extraction}

Genomic bacterial DNA extraction was achieved using the QIAamp DNA Mini kit (Qiagen, Germany, GmbH) according to the manufacturer's recommendations with some modifications. Briefly, S. aureus isolates were cultivated on nutrient agar base (Oxoid, UK) containing 5\% defibrinated sheep blood, followed by incubation at $37^{\circ} \mathrm{C}$ for 24 hours. The colonies were then collected in micro-centrifuge tubes with the aid of $1 \mathrm{ml}$ saline, then $200 \mu \mathrm{l}$ of that saline were incubated with both $10 \mu \mathrm{l}$ of proteinase $\mathrm{K}$ and $200 \mu \mathrm{l}$ lysis buffer for 10 minutes at $56^{\circ} \mathrm{C}$. Then, $200 \mu 1$ of $100 \%$ absolute ethanol was added to the previously formed lysate followed by washing and centrifugation according to the manufacturer's recommendations. The DNAs were eluted with $100 \mu$ l of elution buffer provided in the kit and all extracted DNA were then stored at $-20^{\circ} \mathrm{C}$.

\section{Molecular detection of mecA, vanA, and ermC genes by PCR}

Staphylococcus aureus strains were investigated using polymerase chain reaction (PCR) for the detection of antibiotic resistance genes, including (i) methicillin resistance mecA gene which is a determinant of methicillin resistance in $S$. aureus, (ii) glycopeptide resistance vanA gene which is a determinant for the vancomycin resistance in $S$. aureus, and (iii) ermC gene which is a determinant for the erythromycin resistance in S. aureus (Cai et al., 2021). The PCR amplification was achieved in a $25 \mu \mathrm{l}$ full reaction volume containing $1 \mu \mathrm{l}$ of both forward and reverse primers of 20 pmol concentration, $12.5 \mu \mathrm{l}$ of Emerald Amp Max PCR Master Mix (Takara, Japan), $6 \mu 1$ of DNA template, and $4.5 \mu 1$ of water. After mixing the components of the PCR tube, the solution was then overlaid with $40 \mu$ mineral oil to avoid evaporation then the tubes were placed in an applied biosystem 2720 thermal cycler (PTC100Mil Research, USA). The primers (Metabion, Germany) sequences, amplification cycling condition, and amplified sizes of PCR products are presented in Table 1. 
Table 1. Nucleotide sequences, amplification steps, and amplified PCR products size of Staphylococcus aureus gene-specific oligonucleotide primers

\begin{tabular}{|c|c|c|c|c|c|c|c|c|c|}
\hline \multirow{2}{*}{$\begin{array}{l}\text { Target } \\
\text { gene }\end{array}$} & \multirow{2}{*}{$\begin{array}{c}\text { Primer } \\
\text { name }\end{array}$} & \multirow[b]{2}{*}{ Primers sequences } & \multirow{2}{*}{$\begin{array}{c}\text { Amplified } \\
\text { segment (bp) }\end{array}$} & \multirow{2}{*}{$\begin{array}{c}\text { Primary } \\
\text { denaturation }\end{array}$} & \multicolumn{3}{|c|}{ Amplification ( 35 cycles) } & \multirow{2}{*}{$\begin{array}{c}\text { Final } \\
\text { extension }\end{array}$} & \multirow[b]{2}{*}{ Reference } \\
\hline & & & & & $\begin{array}{c}\text { Secondary } \\
\text { denaturation }\end{array}$ & Annealing & Extension & & \\
\hline \multirow{2}{*}{ mecA } & mecA1 F & GTAGAAATGACTGAACGTCCG ATAA & \multirow{2}{*}{310} & \multirow{2}{*}{$\begin{array}{c}94^{\circ} \mathrm{C} \\
5 \text { minutes }\end{array}$} & \multirow{2}{*}{$\begin{array}{c}94^{\circ} \mathrm{C} \\
45 \text { seconds }\end{array}$} & \multirow{2}{*}{$\begin{array}{c}50^{\circ} \mathrm{C} \\
45 \mathrm{sec} .\end{array}$} & \multirow{2}{*}{$\begin{array}{c}72^{\circ} \mathrm{C} \\
45 \text { seconds }\end{array}$} & \multirow{2}{*}{$\begin{array}{c}72^{\circ} \mathrm{C} \\
10 \text { minutes }\end{array}$} & \multirow{2}{*}{ (Campos-Peña et al., 2014) } \\
\hline & $\operatorname{mec} A 2 \mathrm{R}$ & CCAATTCCACATTGTTTCGGT CTA A & & & & & & & \\
\hline \multirow{2}{*}{ vanA } & $\operatorname{vanA} F$ & CATGAATAGAATAAAAGTTGCAATA & \multirow{2}{*}{1030} & \multirow{2}{*}{$\begin{array}{c}94^{\circ} \mathrm{C} \\
5 \text { minutes }\end{array}$} & \multirow{2}{*}{$\begin{array}{c}94^{\circ} \mathrm{C} \\
30 \text { seconds }\end{array}$} & \multirow{2}{*}{$\begin{array}{c}55^{\circ} \mathrm{C} \\
45 \mathrm{sec}\end{array}$} & \multirow{2}{*}{$\begin{array}{c}72^{\circ} \mathrm{C} \\
1 \text { minute }\end{array}$} & \multirow{2}{*}{$\begin{array}{c}72^{\circ} \mathrm{C} \\
10 \text { minutes }\end{array}$} & \multirow{2}{*}{ (George et al., 2021) } \\
\hline & $\operatorname{vanAR}$ & CCCCTTTAACGCTAATACGATCAA & & & & & & & \\
\hline \multirow[b]{2}{*}{ ermC } & ermC1 F & ATCTTTGAAATCGGCTCAGG & \multirow[b]{2}{*}{295} & \multirow{2}{*}{$\begin{array}{c}94^{\circ} \mathrm{C} \\
5 \text { minutes }\end{array}$} & \multirow{2}{*}{$\begin{array}{c}94^{\circ} \mathrm{C} \\
30 \text { seconds }\end{array}$} & \multirow{2}{*}{$\begin{array}{c}51^{\circ} \mathrm{C} \\
30 \text { seconds }\end{array}$} & \multirow{2}{*}{$\begin{array}{c}72^{\circ} \mathrm{C} \\
30 \text { seconds }\end{array}$} & \multirow{2}{*}{$\begin{array}{c}72^{\circ} \mathrm{C} \\
7 \text { minutes }\end{array}$} & \multirow[b]{2}{*}{ (Schlegelova et al. (2008) } \\
\hline & ermC2 R & CAAACCCGTATTCCACGATT & & & & & & & \\
\hline
\end{tabular}




\section{Agarose gel electrophoresis for PCR product analysis}

PCR products were fragmented by electrophoresis on $1.5 \%$ agarose gel (Applichem, Germany, GmbH) stained with ethidium bromide in $1 \mathrm{X}$ tris-borate-EDTA buffer at room temperature using gradients of $5 \mathrm{~V} / \mathrm{cm}$. For gel analysis, $20 \mu \mathrm{l}$ of the uniplex PCR products were loaded in each gel slot. To determine the amplified fragment size, 100 bp DNA ladder and 100 bp plus DNA Ladders (Qiagen, Germany, GmbH) were used. The gel photos were captured by a gel documentation system (Alpha Innotech, Biometra, Italy) and the output data were examined via automatic computer software (Automatic Image Capture Software, ProteinSimple formerly Cell Biosciences, USA).

\section{Quantitative evaluation of biofilm formation}

Assessment of bacterial biofilm formation was performed as described by Wang et al. (2010). According to OD value, $\mathrm{OD}<0.0112,0.0112 \leq \mathrm{OD}<0.0224,0.0224 \leq \mathrm{OD}<0.0448$, and $\mathrm{OD} \geq 0.0448$ biofilm formations were considered as negative, weak, moderate, and strong biofilm-forming strains respectively.

\section{Statistical analysis}

The statistical analysis of the association between each genotypic and its associated phenotypic antibiotic resistance patterns in each $S$. aureus strain was analyzed and interpreted. Qualitative data were statistically represented in terms of frequency and percentage. Comparison between different groups in the present study was done using the chi-square test with the odds ratio. The probability measure $\mathrm{p}$-value $\leq 0.05$ is considered significant. All statistical calculations were done using SPSS (Statistical Package for Social Science) version 25.

\section{RESULTS}

\section{Isolation and identification of Staphylococcus aureus}

From the results presented in Figure 1, it is clearly shown that, out of the examined 226 milk and dairy products' samples, $157(69.5 \%, 157 / 226)$ were positive for the presence of $S$. aureus. The isolation rates of S. aureus strains from cattle milk, sheep milk, white cheese, flamenco, and mesh samples were as follows; 79.7\% (51), 76.5\% (26), 56.0\% (28), 40.0\% (16), and 94.7\% (36) respectively.

\section{Phenotypic antibiotic resistance profile of the isolated Staphylococcus aureus}

Table 2 shows the phenotypic antibiotic resistance features of the isolated $S$. aureus isolates within each category of samples (cattle milk, sheep milk, white cheese, flamenco, and mesh). Percent of $S$. aureus resistance to the number of antibiotics within each category of samples is presented in Figure 2. Notably, 22.3\% (35), 16.6\% (26), and 51.0\% (80) of all isolated $S$. aureus strains indicated resistance to one, two, and more than two (MDR) antimicrobial agents respectively. Multidrug-resistant $S$. aureus isolates were detected in $80.4 \%$ (41), $57.7 \%$ (15), $64.3 \%$ (18), $18.8 \%$ (3), and $8.3 \%$ (3) of the $S$. aureus strains isolated from cattle milk, sheep milk, white cheese, flamenco, and mesh respectively.

\section{Genotypic antibiotic resistance features of the isolated Staphylococcus aureus}

Genotypic detection of $m e c A$, vanA, and ermC genes within $S$. aureus isolates is presented in Table 3 . Notably, $72.6 \%$ (114), $40.1 \%$ (63), and $48.4 \%$ (76) of $S$. aureus isolates were carriers for mecA, vanA, and ermC genes respectively, and the amplified products were at 310, 1030, and 295 bp respectively as presented in Figures 3-5.

Statistical association between genotypic and phenotypic antibiotics resistance features of the isolated Staphylococcus aureus

Genotypic and its related phenotypic antibiotics resistance features of $S$. aureus within each category of samples (cattle milk, sheep milk, white cheese, flamenco, and mesh) are presented in Table 3 and Figures 6-9. The statistical analysis of the association between each genotypic and its related phenotypic antibiotics resistance features within all isolated $S$. aureus isolates is presented in Table 4.

\section{Biofilm forming ability of MRSA isolates}

The biofilm formation assay revealed that $6.8 \%$ (5) of MRSA isolates exhibit weak biofilm-forming ability while $93.2 \%$ (69) exhibit no biofilm-forming ability. 
Table 2. Phenotypic antibiotic resistance features of Staphylococcus aureus strains within each category of samples (cattle milk, sheep milk, white cheese, flamenco, and mesh)

\begin{tabular}{|c|c|c|c|c|c|c|c|c|c|c|c|c|c|c|c|c|c|c|c|c|c|}
\hline \multirow{4}{*}{ Antimicrobial } & \multicolumn{21}{|c|}{ Antimicrobial susceptibility of the tested Staphylococcus aureus isolated from milk and cheese } \\
\hline & \multicolumn{8}{|c|}{ Tested Staphylococcus aureus isolated from milk } & \multicolumn{11}{|c|}{ Tested Staphylococcus aureus isolated from cheese } & \multirow{2}{*}{\multicolumn{2}{|c|}{$\frac{\text { Total R }}{(\text { no=157) }}$}} \\
\hline & \multicolumn{3}{|c|}{$\begin{array}{c}\text { Cattle milk } \\
(\text { no=51) }\end{array}$} & \multicolumn{3}{|c|}{$\begin{array}{l}\text { Sheep milk } \\
(\text { no =26) }\end{array}$} & \multicolumn{2}{|c|}{$\begin{array}{c}\text { Total milk } \\
\text { resistance } \\
(\text { no=77) }\end{array}$} & \multicolumn{3}{|c|}{$\begin{array}{l}\text { White cheese } \\
\text { (no=28) }\end{array}$} & \multicolumn{3}{|c|}{$\begin{array}{c}\text { Flamenco } \\
(\mathrm{no}=16)\end{array}$} & \multicolumn{3}{|c|}{$\begin{array}{c}\text { Mesh } \\
(\text { no=36) }\end{array}$} & \multicolumn{2}{|c|}{$\begin{array}{c}\text { Total Cheese } \\
\text { Resistance } \\
(\text { no=80) }\end{array}$} & & \\
\hline & $\mathbf{S}$ & $\mathbf{I}$ & $\mathbf{R}$ & $\mathbf{S}$ & $\mathbf{I}$ & $\mathbf{R}$ & No. & $\%$ & $\mathbf{S}$ & $\mathbf{I}$ & $\mathbf{R}$ & $\mathbf{S}$ & $\mathbf{I}$ & $\mathbf{R}$ & $\mathbf{S}$ & $\mathbf{I}$ & $\mathbf{R}$ & No. & $\%$ & No. & $\%$ \\
\hline Penicillin & 3 & 0 & 48 & 6 & 0 & 20 & 68 & 88.3 & 12 & 0 & 16 & 11 & 0 & 5 & 27 & 0 & 9 & 30 & 34.1 & 98 & 62.4 \\
\hline Oxacillin & 11 & 0 & 40 & 11 & 0 & 15 & 55 & 71.4 & 5 & 0 & 23 & 12 & 0 & 4 & 16 & 0 & 20 & 47 & 53.4 & 102 & 65.0 \\
\hline Vancomycin & 38 & 0 & 13 & 8 & 0 & 18 & 31 & 40.3 & 5 & 0 & 23 & 13 & 0 & 3 & 23 & 0 & 13 & 39 & 44.3 & 70 & 44.6 \\
\hline Erythromycin & 8 & 0 & 43 & 8 & 0 & 18 & 61 & 79.2 & 17 & 0 & 11 & 16 & 0 & 0 & 36 & 0 & 0 & 11 & 12.5 & 72 & 45.9 \\
\hline Clindamycin & 42 & 0 & 9 & 23 & 0 & 3 & 12 & 15.6 & 16 & 12 & 0 & 7 & 4 & 5 & 29 & 2 & 5 & 10 & 11.4 & 22 & 14.0 \\
\hline Trimethoprim-Sulfamethoxazole & 51 & 0 & 0 & 26 & 0 & 0 & 0 & 0.0 & 28 & 0 & 0 & 16 & 0 & 0 & 36 & 0 & 0 & 0 & 0.0 & 0 & 0.0 \\
\hline Linezolid & 51 & 0 & 0 & 26 & 0 & 0 & 0 & 0.0 & 28 & 0 & 0 & 16 & 0 & 0 & 36 & 0 & 0 & 0 & 0.0 & 0 & 0.0 \\
\hline Tetracycline & 23 & 8 & 20 & 7 & 6 & 13 & 33 & 42.9 & 28 & 0 & 0 & 16 & 0 & 0 & 36 & 0 & 0 & 0 & 0.0 & 33 & 21.0 \\
\hline Rifampin & 43 & 0 & 8 & 23 & 3 & 0 & 8 & 10.4 & 28 & 0 & 0 & 11 & 5 & 0 & 36 & 0 & 0 & 0 & 0.0 & 8 & 5.1 \\
\hline Chloramphenicol & 50 & 0 & 1 & 23 & 0 & 3 & 4 & 5.2 & 28 & 0 & 0 & 16 & 0 & 0 & 36 & 0 & 0 & 0 & 0.0 & 4 & 2.5 \\
\hline Ciprofloxacin & 51 & 0 & 0 & 26 & 0 & 0 & 0 & 0.0 & 28 & 0 & 0 & 16 & 0 & 0 & 36 & 0 & 0 & 0 & 0.0 & 0 & 0.0 \\
\hline Gentamycin & 51 & 0 & 0 & 26 & 0 & 0 & 0 & 0.0 & 28 & 0 & 0 & 12 & 4 & 0 & 36 & 0 & 0 & 0 & 0.0 & 0 & 0.0 \\
\hline
\end{tabular}

S= sensitive, I= intermediate, $\mathrm{R}=$ resistance 
Table 3. Genotypic and its related phenotypic antibiotics resistance features of Staphylococcus aureus within each category of samples

\begin{tabular}{|c|c|c|c|c|c|c|c|c|c|c|c|c|c|c|c|c|c|c|c|c|c|c|c|c|c|}
\hline \multirow{3}{*}{ Samples } & & \multicolumn{12}{|c|}{ mecA gene and Penicillin and/or Oxacillin resistance } & \multicolumn{6}{|c|}{ vanA gene and Vancomycin resistance } & \multicolumn{6}{|c|}{ erm $C$ gene and Erythromycin resistance } \\
\hline & \multirow{2}{*}{$\begin{array}{c}\text { No of } \\
\text { S. } \\
\text { aureus } \\
\text { isolates }\end{array}$} & \multicolumn{2}{|c|}{$\begin{array}{c}\text { mecA } \\
\text { gene }\end{array}$} & \multicolumn{2}{|c|}{ Penicillin } & \multicolumn{2}{|c|}{ Oxacillin } & \multicolumn{2}{|c|}{$\begin{array}{c}\text { mecA } \\
\text { and } \\
\text { Penicillin }\end{array}$} & \multicolumn{2}{|c|}{$\begin{array}{c}\text { mecA } \\
\text { and } \\
\text { Oxacillin }\end{array}$} & \multicolumn{2}{|c|}{$\begin{array}{l}\text { mecA and } \\
\text { Penicillin } \\
\text { and } \\
\text { Oxacillin }\end{array}$} & \multicolumn{2}{|c|}{ vanA gene } & \multicolumn{2}{|c|}{ Vancomycin } & \multicolumn{2}{|c|}{$\begin{array}{c}\operatorname{van} A \\
\text { and } \\
\text { Vancomycin }\end{array}$} & \multicolumn{2}{|c|}{$\begin{array}{c}\text { erm } C \\
\text { gene }\end{array}$} & \multicolumn{2}{|c|}{ Erythromycin } & \multicolumn{2}{|c|}{$\begin{array}{c}\text { ermC } \\
\text { and } \\
\text { Erythromycin }\end{array}$} \\
\hline & & No & $\%$ & No & $\%$ & No & $\%$ & No & $\%$ & No & $\%$ & No & $\%$ & No & $\%$ & No & $\%$ & No & $\%$ & No & $\%$ & No & $\%$ & No & $\%$ \\
\hline Cattle milk & 51 & 46 & 90.2 & 48 & 94.1 & 40 & 78.4 & 45 & 88.2 & 39 & 76.5 & 39 & 76.5 & 10 & 19.6 & 13 & 25.5 & 8 & 15.7 & 45 & 88.2 & 43 & 84.3 & 42 & 82.4 \\
\hline Sheep milk & 26 & 20 & 76.9 & 20 & 76.9 & 15 & 57.7 & 17 & 65.4 & 12 & 46.2 & 12 & 46.2 & 18 & 69.2 & 18 & 69.2 & 15 & 57.7 & 20 & 76.9 & 18 & 69.2 & 15 & 57.7 \\
\hline Total milk & 77 & 66 & 85.7 & 68 & 88.3 & 55 & 71.4 & 62 & 80.5 & 51 & 66.2 & 51 & 66.2 & 28 & 36.4 & 31 & 40.3 & 23 & 29.9 & 65 & 84.4 & 61 & 79.2 & 57 & 74.0 \\
\hline White cheese & 28 & 23 & 82.1 & 16 & 57.1 & 23 & 82.1 & 15 & 53.6 & 20 & 71.4 & 14 & 50.0 & 21 & 75.0 & 23 & 82.1 & 21 & 75.0 & 11 & 39.3 & 11 & 39.3 & 10 & 35.7 \\
\hline Flamenco & 16 & 5 & 31.3 & 5 & 31.3 & 4 & 25.0 & 3 & 18.8 & 2 & 12.5 & 2 & 12.5 & 3 & 18.8 & 3 & 18.8 & 1 & 6.3 & 0 & 0.0 & 0 & 0.0 & 0 & 0.0 \\
\hline Mesh & 36 & 20 & 55.6 & 9 & 25.0 & 20 & 55.6 & 7 & 19.4 & 19 & 52.8 & 7 & 19.4 & 11 & 30.6 & 13 & 36.1 & 10 & 27.8 & 0 & 0.0 & 0 & 0.0 & 0 & 0.0 \\
\hline Total cheese & 80 & 51 & 63.8 & 30 & 37.5 & 51 & 63.8 & 27 & 33.8 & 46 & 57.5 & 26 & 32.5 & 40 & 50.0 & 45 & 56.3 & 39 & 48.8 & 15 & 18.8 & 15 & 18.8 & 14 & 17.5 \\
\hline Total sample & 157 & 114 & 72.6 & 98 & 62.4 & 102 & 65.0 & 87 & 55.4 & 92 & 58.6 & 74 & 47.1 & 63 & 40.1 & 70 & 44.6 & 55 & 35.0 & 76 & 48.4 & 72 & 45.9 & 67 & 42.7 \\
\hline
\end{tabular}


Table 4. The association between each genotypic and its related phenotypic antibiotics resistance features within all Staphylococcus aureus isolated from milk and dairy products

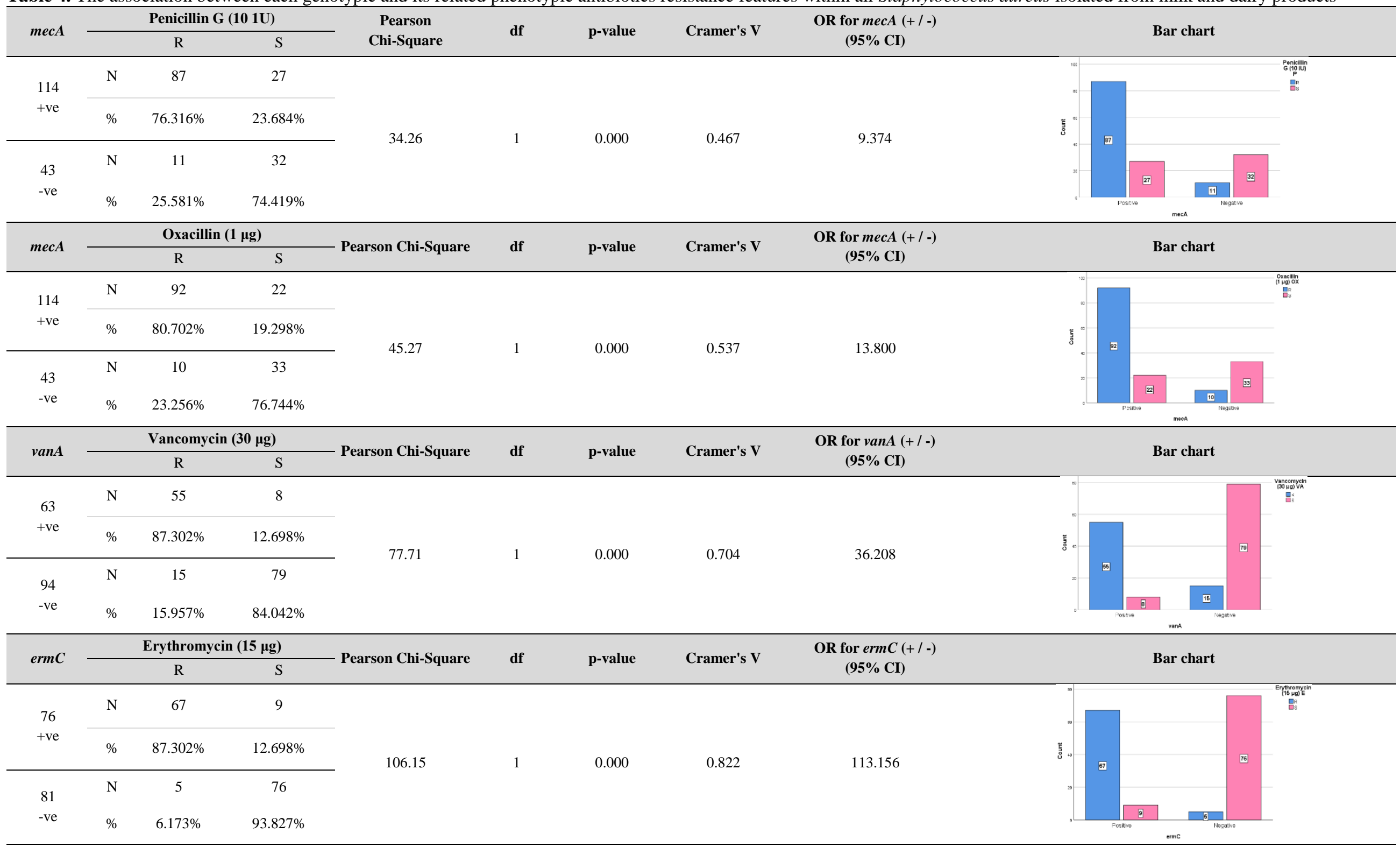

$\mathrm{p} \leq 0.05$ is considered statistically significant, OR: Odd ratio, R: Resistant, S: Sensetive, df: Degree of freedom, + / -: Presence/ absence, $95 \%$ CI: $95 \%$ Confidence Interval 


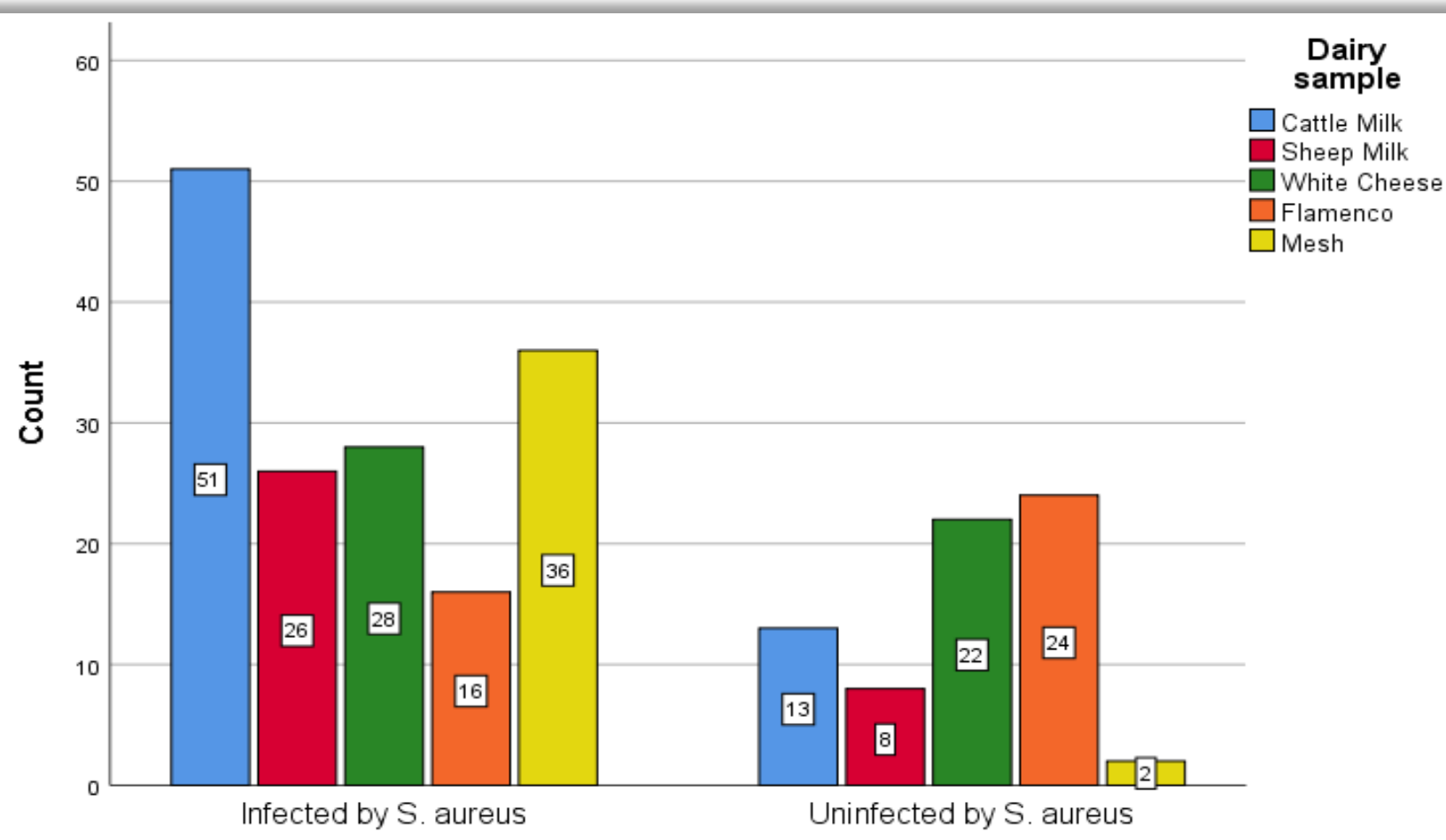

Infection with S. aureus

Figure 1. Contamination status of dairy samples by Staphylococcus aureus. The contamination rates caused by $S$. aureus within cattle milk, sheep milk, white cheese, flamenco, and mesh samples were 79.7\% (51), 76.5\% (26), 56.0\% (28), 40.0\% (16), and $94.7 \%$ (36) respectively.

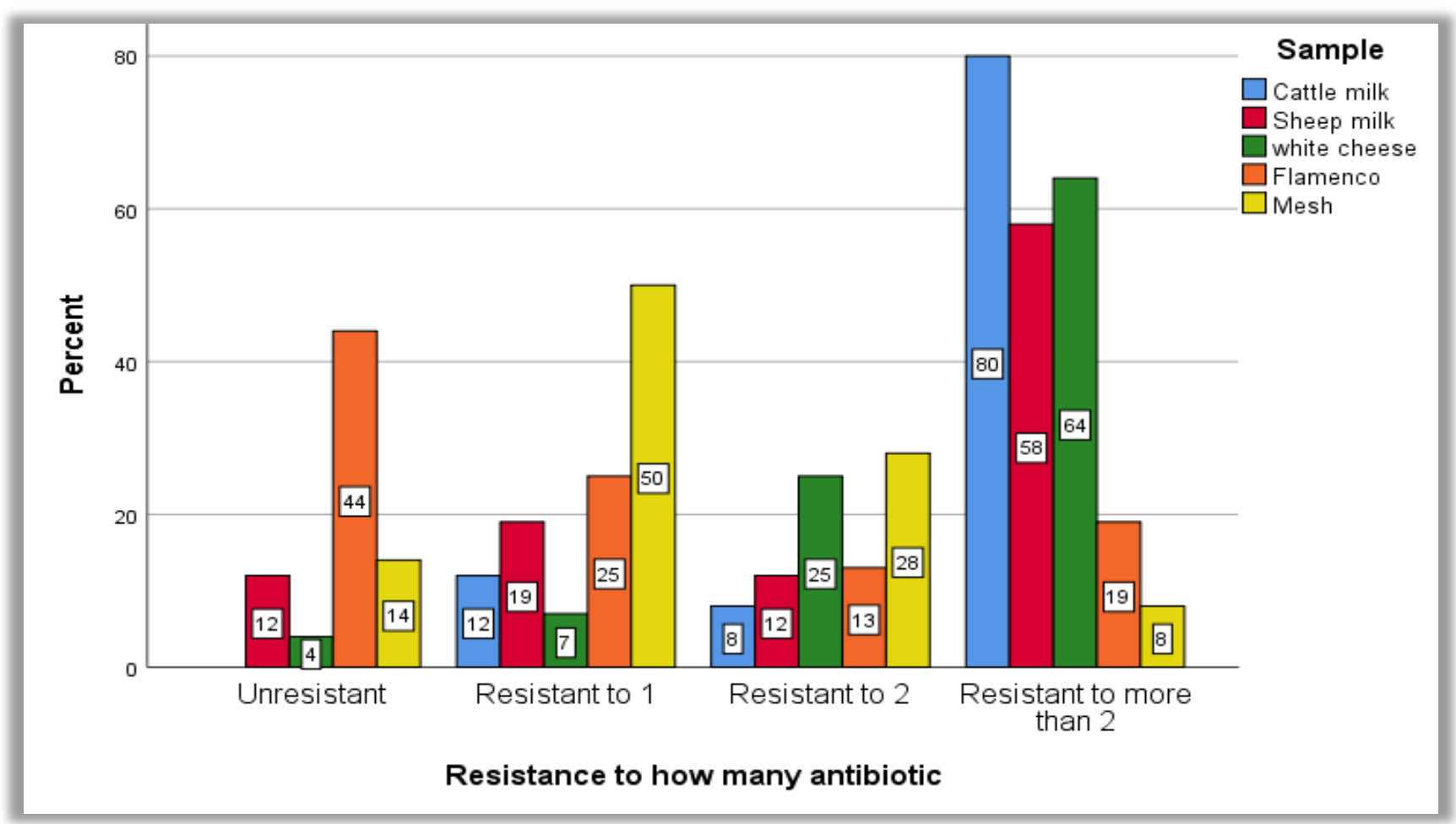

Figure 2. Percent of Staphylococcus aureus resistance to how many antibiotics within each category of sample. Multidrug-resistant $S$. aureus isolates were detected in $80.4 \%$ (41), $57.7 \%$ (15), 64.3\% (18), $18.8 \%$ (3), and 8.3\% (3) of the S. aureus isolated from cattle milk, sheep milk, white cheese, flamenco, and mesh respectively. 


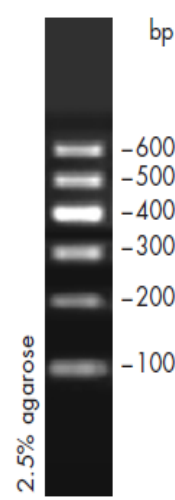

GelPilot 100 bp Ladder (100) (cat. no. 239035 )

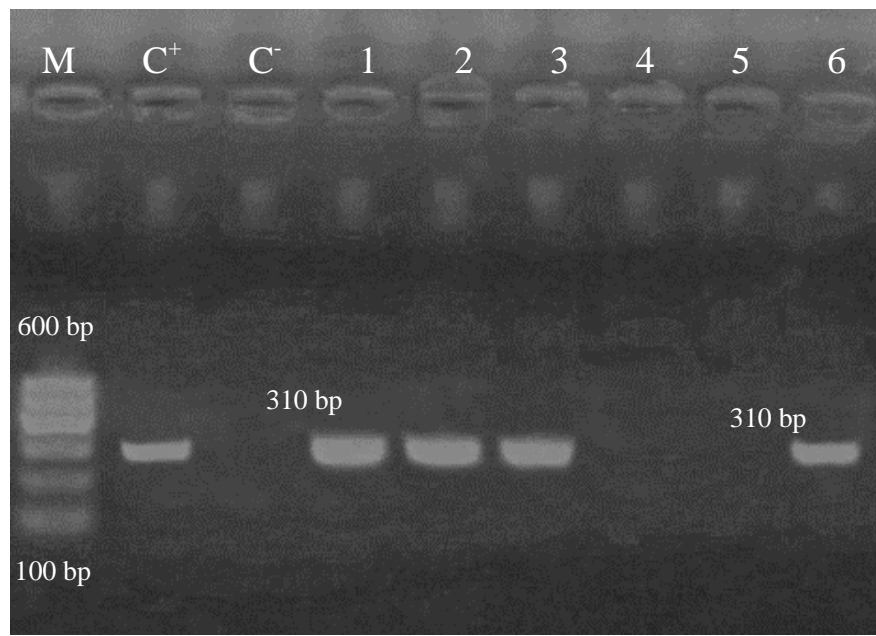

Figure 3. PCR amplified products of $m e c A$ gene at 310 bp among Staphylococcus aureus isolated from cattle milk. Lanes (M): QIAGEN GelPilot DNA 100 bp ladder; lanes $\left(\mathrm{C}^{+}\right)$: positive control Staphylococcus aureus (mecA positive); lanes $\left(\mathrm{C}^{-}\right)$: negative control Staphylococcus aureus (mecA negative); lanes (1-6): Staphylococcus aureus isolates from cattle milk; lane 1,2,3,6: positive samples of mecA gene (310 bp); lane 4,5: negative samples of mecA gene.
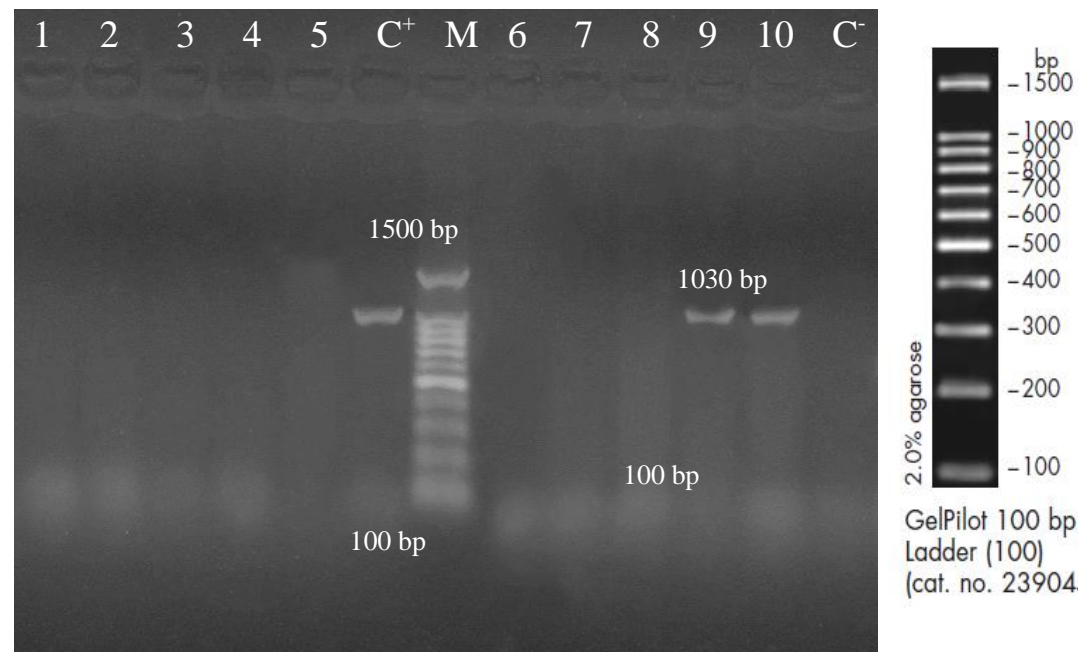

GelPilot 100 bp Plus

Ladder (100)

(cat. no. 239045)

Figure 4. PCR amplified products of vanA gene at $1030 \mathrm{bp}$ among Staphylococcus aureus isolated from dairy products. Lanes (M): QIAGEN GelPilot DNA 100 bp plus ladder; lanes $\left(\mathrm{C}^{+}\right)$: positive control Staphylococcus aureus (vanA positive); lanes (C ): negative control Staphylococcus aureus (vanA negative); lanes (1-10): Staphylococcus aureus isolates isolated from dairy products; lane 9,10: positive samples of $v a n A$ gene (1030 bp); lane 1,2,3,4,5,6,7,8: negative samples of vanA gene.
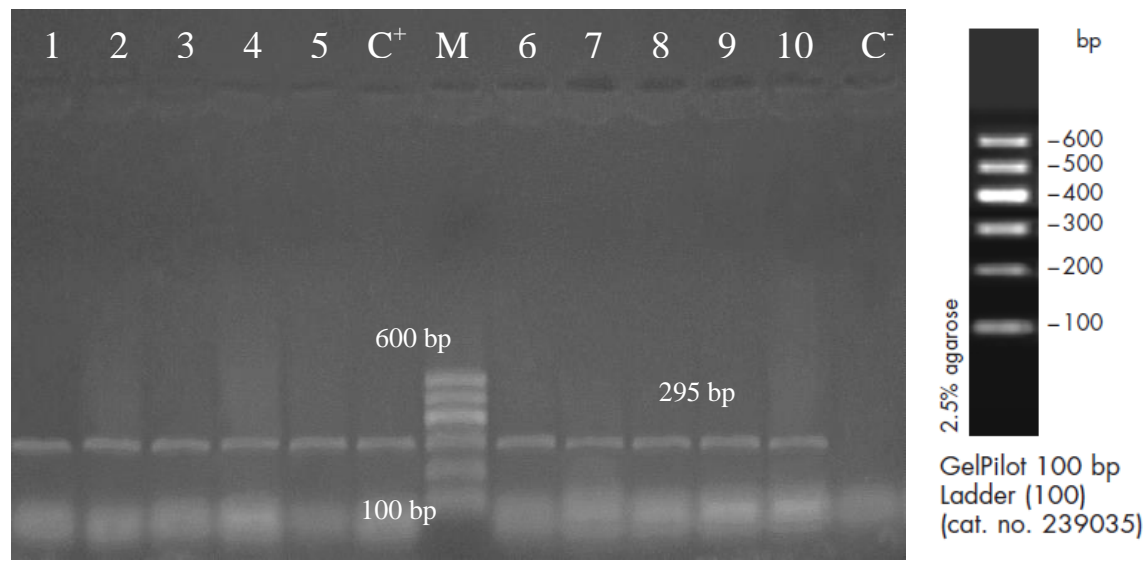

Figure 5. PCR amplified products of ermC gene at 295 bp among Staphylococcus aureus isolated from cattle milk. Lanes (M): QIAGEN GelPilot DNA 100 bp ladder; lanes $\left(\mathrm{C}^{+}\right)$: positive control Staphylococcus aureus (ermC positive); lanes $\left(\mathrm{C}^{-}\right)$: negative control Staphylococcus aureus (ermC negative); lanes (1-10): Staphylococcus aureus isolates isolated from cattle milk; lane (1-10): positive samples of ermC gene (295 bp). 


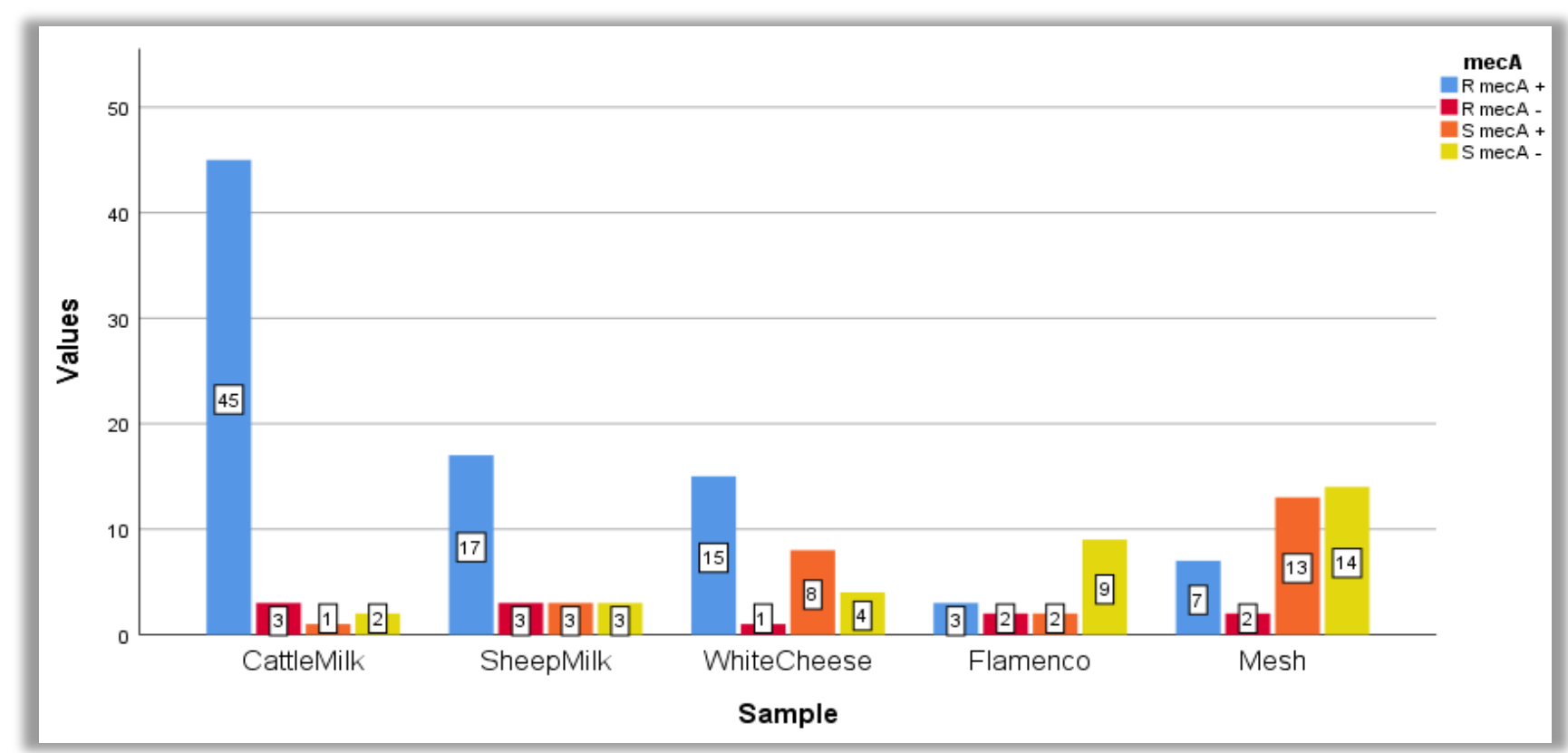

Figure 6. Presence (+) or absence (-) of mecA gene versus penicillin G (10 IU) resistance (R) or sensitivity (S) in Staphylococcus aureus isolated from each category of sample (cattle milk, sheep milk, white cheese, flamenco, and mesh). The presence of mecA gene in Staphylococcus aureus is statistically associated with its encoding phenotypic resistance patterns against penicillin. Along with an increase in the frequency of $m e c A$ gene, the resistance rate to penicillin sharply increased.

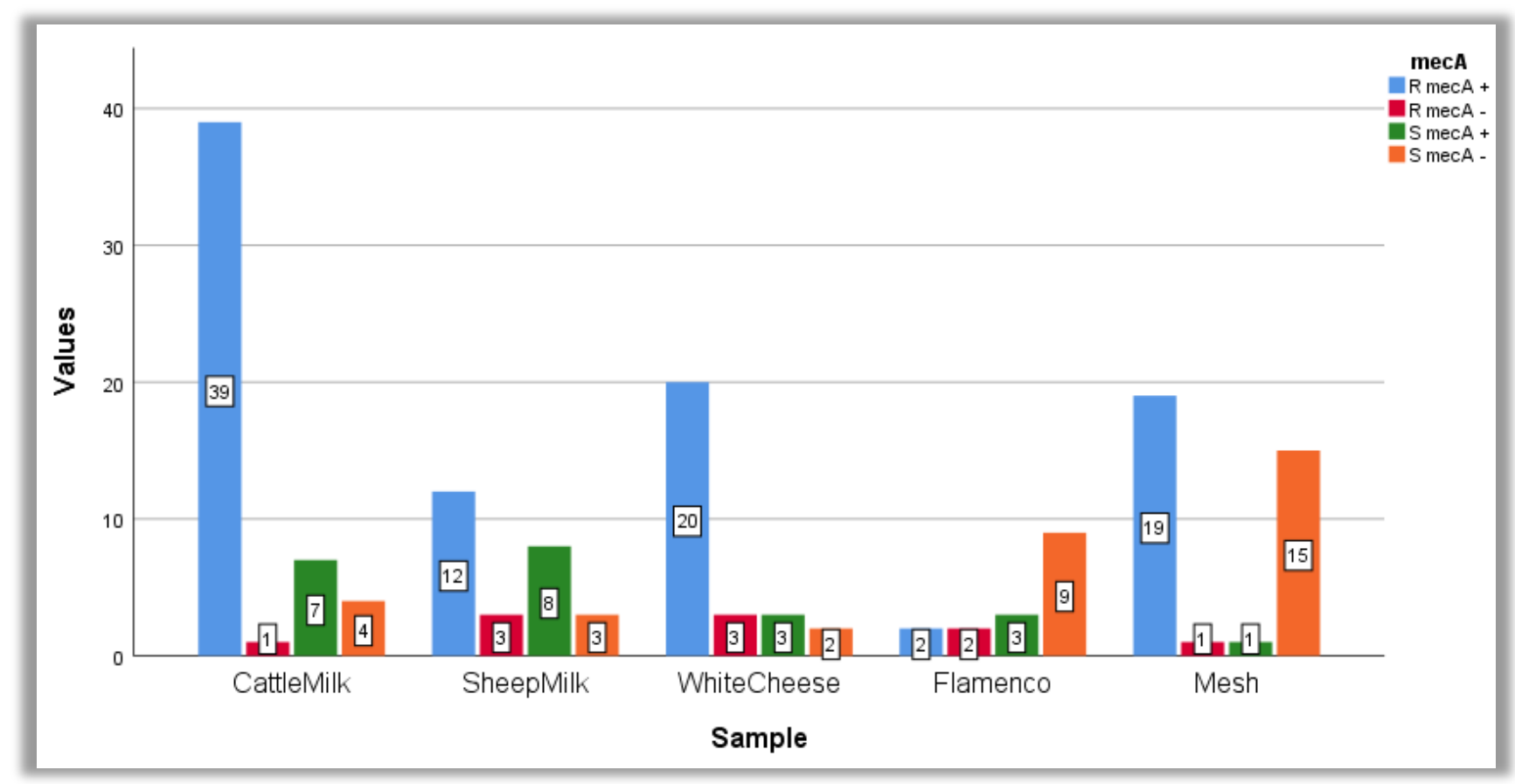

Figure 7. Presence (+) or absence (-) of mecA gene versus oxacillin $(1 \mu \mathrm{g})$ resistance (R) or sensitivity (S) in Staphylococcus aureus isolated from each category of the sample (cattle milk, sheep milk, white cheese, flamenco, and mesh). The presence of mecA gene in Staphylococcus aureus is statistically associated with its encoding phenotypic resistance patterns against oxacillin. Along with an increase in the frequency of $m e c A$ gene, the resistance rate to oxacillin sharply increased. 


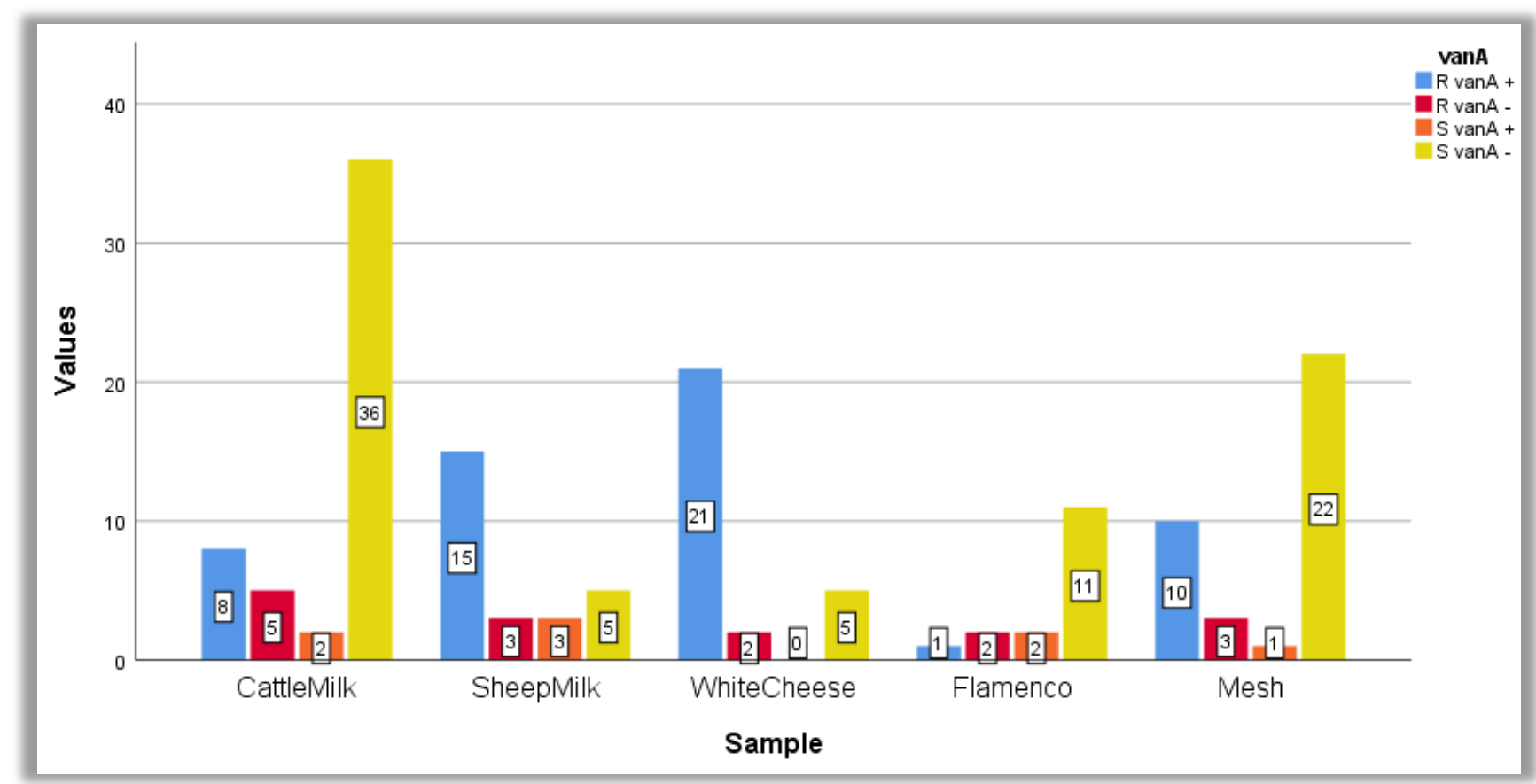

Figure 8. Presence (+) or absence (-) of vanA gene versus vancomycin (30 $\mu \mathrm{g})$ resistance (R) or sensitivity (S) in Staphylococcus aureus isolated from each category of the sample (cattle milk, sheep milk, white cheese, flamenco, and mesh). The presence of vanA gene in Staphylococcus aureus is statistically associated with its encoding phenotypic resistance patterns against vancomycin. Along with an increase in the frequency of vanA gene, the resistance rate to vancomycin sharply increased.

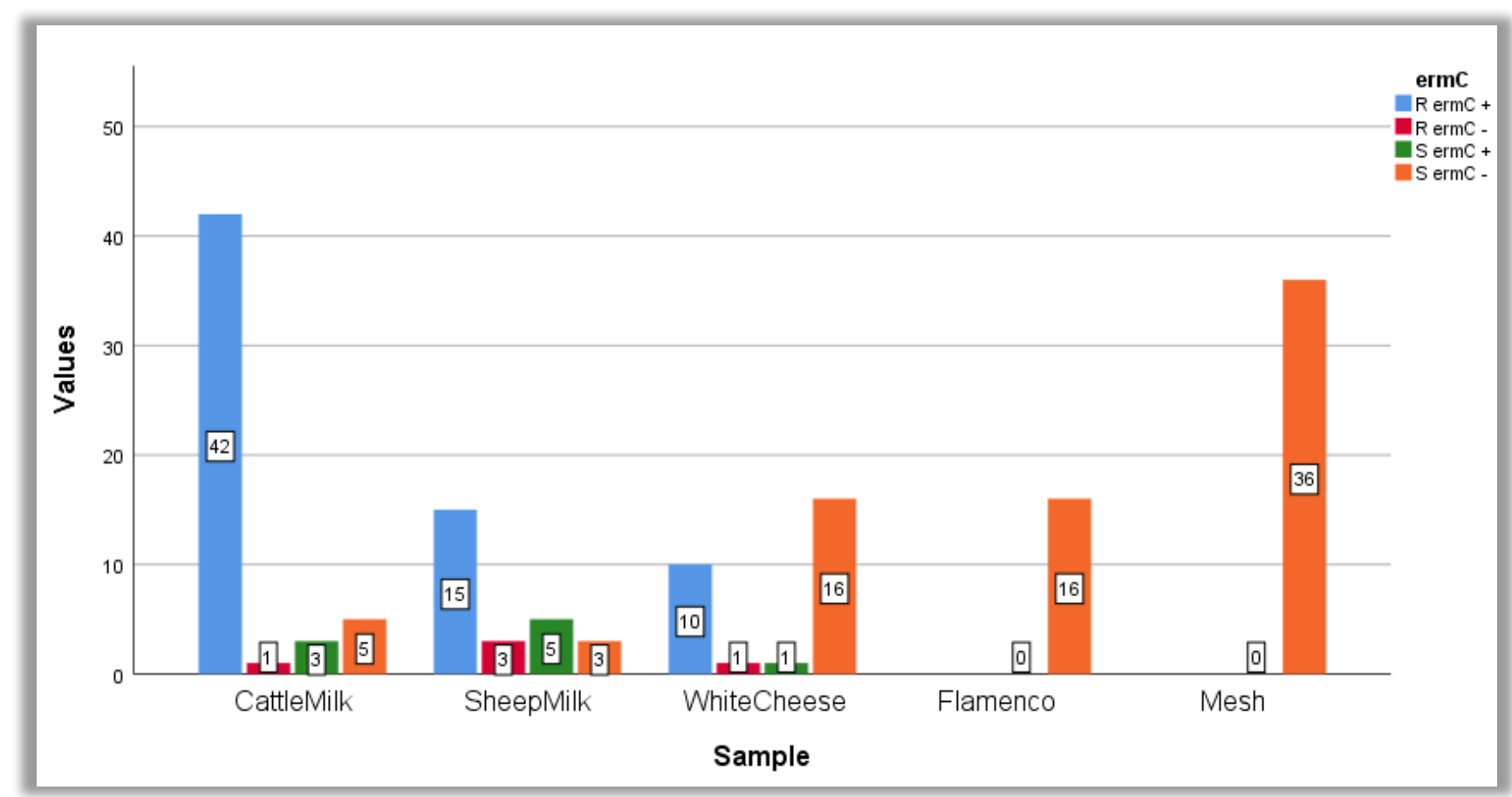

Figure 9. Presence (+) or absence (-) of ermC gene versus erythromycin (15 $\mu \mathrm{g})$ resistance (R) or sensitivity (S) in Staphylococcus aureus isolated from each category of the sample (cattle milk, sheep milk, white cheese, flamenco, and mesh). The presence of ermC gene in Staphylococcus aureus is statistically associated with its encoding phenotypic resistance patterns against erythromycin. Along with an increase in the frequency of erm $C$ gene, the resistance rate to erythromycin sharply increased. 


\section{DISCUSSION}

Staphylococcus aureus is considered a dangerous human pathogen that causes a wide range of diseases varying from mild to life-threatening illnesses. This bacterium is also considered one of the main causes of food intoxication in human beings (Zayda et al., 2020). In the current study, 69.5\% out of the examined 226 milk and dairy samples were positive for the presence of $S$. aureus. Contamination of dairy products with $S$. aureus was also studied in many previous research articles. For example, in a previous study, out of the examined 144 retail raw milk samples collected from different regions in China, $43.1 \%$ were contaminated by $S$. aureus with the highest isolation rate of $61.7 \%$ from cow milk (Kou et al., 2021) which is considered a high incidence rate as that recorded in the current study. Moreover, $29 \%$ of the examined milk samples were positive for S. aureus (Angelidis et al., 2020) which was lower than the obtained results of the present study. Also, $16.6 \%$ of $S$. aureus contaminations were previously recorded in the examined milk samples (Regasa et al., 2019) which also was lower than the reported value of the current investigation. Further, 14\% of the examined cheese samples which were collected from Altay, Yining, and Tacheng, were positive for the presence of S. aureus (Cai et al., 2021) which is lower than the current study. Contamination of dairy products with S. aureus can occur during the production process of dairy products through using raw milk for fermentation and cheese production in an unsanitary working environment in dairy farms. The longer the production line, the higher the prevalence of $S$. aureus contamination in cheese products. Another important element is the hygiene level of the workers. Most retailers do not necessitate sterile packaging standards of cheese but they rather have them be dried in a natural environment. This inevitably leads to an increased probability of $S$. aureus prevalence rates (Cai et al., 2021). The above observations advise that an effective sanitary barrier is imperative for cheese production. The current study illustrates that there is room for improvement in these aspects so it is advisable to establish new ways to improve better hygiene practices in the production and processing of dairy products. In addition, it is imperative to conduct professional training for workers in each step of milk collection and dairy products production.

On the other hand, S. aureus bacterium is famous for its resistance against a wide range of antibiotics (Cheung et al., 2021). The existence of antibiotic-resistant $S$. aureus is a substantial issue that threatens human life (Frieri et al., 2017). In the current study, $22.3 \%, 16.6 \%$, and $51.0 \%$ of all isolated S. aureus strains indicated resistance to one, two, and more than two (MDR) antimicrobial agents. The antimicrobial resistance patterns were also studied in many previous research articles. For example, $36.3 \%, 46.6 \%$, and $12.8 \%$, S. aureus strains isolated from milk and dairy products showed resistance to one, two, and more than two antimicrobial agents respectively which slightly vary from the present investigation (Jamali et al., 2015). Furthermore, 80.6\% of S. aureus strains isolated from retail raw milk samples in northern Xinjiang, China, were resistant to at least one antibiotic, while $46.8 \%$ were resistant to three or more antibiotics which are nearly similar to the current investigation (Kou et al., 2021). Multidrug-resistant $S$. aureus was also detected in $15.4 \%, 14.3 \%$, and $8.1 \%$ of $S$. aureus strains isolated from cow milk, cheese, and sheep milk respectively (Jamali et al., 2015). Moreover, MDR S. aureus was also detected in $27.4 \%$ of S. aureus strains isolated from cheese (Cai et al., 2021).

In the current study, clindamycin and chloramphenicol resistance in all isolated S. aureus strains were $14.0 \%$ and $2.5 \%$ respectively. Mostly like the present investigation, S. aureus strains isolated from 2650 milk and dairy products' samples, including cow milk, sheep milk, and cheese showed $11.3 \%$ clindamycin and $3.7 \%$ chloramphenicol resistance (Jamali et al., 2015). Moreover, 0.5\% chloramphenicol resistance was detected among S. aureus strains isolated from raw milk samples (Rola et al., 2015). However, $24.2 \%$ of S. aureus strains isolated from cheese samples showed clindamycin resistance (Cai et al., 2021) which was higher than that of the current study. On the other hand, the high resistance level of $S$. aureus has been previously reported against methicillin, tetracycline, gentamicin, kanamycin, and streptomycin (Jamali et al., 2015). In the current study, the tetracycline resistance in S. aureus strains was $21.0 \%$. In previous studies, $56.1 \%, 6.3 \%$, and $0.9 \%$ of $S$. aureus strains showed tetracycline resistance in surveys done by Jamali et al. (2015), Rola et al. (2015), and Antonios et al. (2015) respectively. Data presented in the current study revealed that all tested $S$. aureus strains were sensitive to trimethoprim-sulfamethoxazole, linezolid, ciprofloxacin, and gentamycin. Consistent with the current study, Jamali et al. (2015) indicated that all of the isolated S. aureus strains from 2650 samples of milk and dairy products including cow milk, sheep milk, and cheese were susceptible to trimethoprim-sulfamethoxazole and ciprofloxacin.

In the present study, the resistance against penicillin and oxacillin in S. aureus strains was $62.4 \%$ and $65.0 \%$ respectively. The observed resistance to penicillin and oxacillin in S. aureus strains represents an alarming indicator for the presence of phenotypic methicillin-resistant $S$. aureus (MRSA) which is considered a public health hazard. In a previous study, $95.3 \%$ of the isolated S. aureus strains showed penicillin resistance which is greater than the current study (Beyene et al., 2017). Also, $72.6 \%$ of the isolated S. aureus strains from milk samples showed penicillin resistance which is greater than the current study (Kou et al., 2021). However, penicillin resistance was $15.5 \%$ in another study (Rola et al., 2015) which is lower than the current study. In agreement with the present study, phenotypic MRSA revealed resistance to both penicillin and oxacillin (Chajęcka-Wierzchowska et al., 2015; Regasa et al., 2019) Oxacillin-resistant $S$. aureus was also identified previously as MRSA (Jamali et al., 2015). 
Notably, livestock and their products are possible reservoirs for MDR phenotypic $S$. aureus due to the extensive utilization of antibacterial agents during livestock production (Zayda et al., 2020). In veterinary practice, S. aureus can easily acquire resistance to antibiotics due to extensive utilization of antibacterial agents either to control bacterial infections or to speed up animal growth rate (Frieri et al., 2017). It is actually difficult to compare the results of the current study with other studies on the prevalence of resistance characteristics of $S$. aureus in milk and dairy products due to the scarcity of research regarding these issues. However, the difference between different studies on the prevalence rate of antibiotic resistance $S$. aureus in milk and dairy products is primarily caused by the differences in the country, animal species, livestock breeding system, and sanitary conditions in the milking environment.

The isolated $S$. aureus strains were screened for the presence of $m e c A$, vanA, and erm $C$ genes. In the current study, $72.6 \%$ of the isolated $S$. aureus strains were carriers for mecA gene. The presence of $m e c A$ gene confirms the presence of MRSA as previously mentioned by Zhang et al. (2016). Many S. aureus strains can be converted to MRSA due to mecA gene acquisition (Zhang et al., 2016). The presence of mecA gene revealed in turn phenotypic methicillin resistance in all genotypic MRSA strains as previously mentioned by Chajęcka-Wierzchowska et al. (2015). Moreover, Zayda et al. (2020) reported that $100 \%$ of the phenotypic oxacillin-resistant MRSA isolates were genotypic mecA positive. Zhang et al. (2016) reported that when only the isolates were both mecA positive and cefoxitin resistant, they can be then classified as MRSA strains. In another study, more than $63 \%$ of $S$. aureus isolates were carriers of $m e c A$ gene, and so are considered MRSA strains (Houri et al., 2020). Although 7 S. aureus strains showed resistance to oxacillin $\left(0.25 \mu \mathrm{g} \mathrm{ml}^{-1}\right)$, they cannot be characterized as MRSA strains because they were mecA negative (Antonios et al., 2015). Therefore, a combination of genotypic and phenotypic characterizations is necessary for the confirmation of the presence of MRSA to avoid false positive or false negative MRSA confirmation (Zhang et al., 2016). In the present study, detection of MRSA isolates was done using both phenotypic and genotypic confirmation; i.e if the isolate is both penicillin and oxacillin resistant in addition to its acquisition of mecA gene, it is then identified as MRSA strain. Accordingly, it was indicated that $47.1 \%$ of all tested $S$. aureus strains were characterized as MRSA strains. The MRSA is also noticed by many other research articles with high incidence (Houri et al., 2020). For example, in a previous study, $21 \%$ of $S$. aureus strains isolated from cheese samples were identified as MRSA strains (Cai et al., 2021). In addition, $51.6 \%$ of the isolated S. aureus strains from milk samples were identified as MRSA strains (Kou et al., 2021) which is nearly similar to the present study. However, 5.4\% of MRSA levels were noticed in the buffalo bulk tank milk in Italy which is lower than the present study (Giovanni et al., 2020). Further, 100\% of oxacillin resistant S. aureus strains isolated from milk and cheese samples, were mecA gene positive confirming the presence of MRSA isolates (Zayda et al., 2020). MRSA was detected in nine S. aureus isolates which were carriers for mecA gene (Angelidis et al., 2020). Further, $2 \%$ of MRSA strains were isolated from milk and cheese (Jamali et al., 2015) which is less than the current study. Antimicrobials from five major classes, including $\beta$-lactams, aminoglycosides, tetracyclines, sulphonamides, and macrolides are the most commonly used antimicrobials in veterinary practice to control bacterial diseases in herds. However, inappropriate use of these antimicrobials for a long time has been considered to be responsible for the gradual development of resistance in S. aureus (Cai et al., 2021). $\beta$-lactams are the most widely used antimicrobials for treating dairy farms' infections. This may be the reason for such a high incidence rate of MRSA among dairy products (Jamali et al., 2015; Rola et al., 2015). The $\beta$-lactam resistance feature in MRSA is mainly based on two mechanisms; the first is the production of $\beta$-lactamases; an extracellular enzyme which is synthesized when staphylococci are exposed to the $\beta$-lactam (Panchal et al., 2020). The second is via the production of a low-affinity penicillin-binding protein 2a (PBP2a) which is controlled by mecA gene which codes for the PBP2a protein. mecA gene mediates resistance to all classes of the $\beta$-lactam antibiotics, including methicillin, oxacillin, and cephalosporins (Panchal et al., 2020). On the other hand, Chajęcka-Wierzchowska et al. (2015) reported that MRSA was phenotypic resistant to all $\beta$-lactam antibiotics, penicillins, amino-penicillins, isoxazolyl-penicillins.

In the present study, $40.1 \%$ of the isolated $S$. aureus strains were carriers for vanA gene while $44.6 \%$ of them were phenotypic vancomycin-resistant. Of the phenotypic vancomycin resistance $S$. aureus strains, $78.6 \%$ were genotypic vanA gene carriers representing VRSA strains however the remaining 21.4\% were vanA negative. Frieri et al. (2017) documented that the horizontal transferable silenced vanA can escape detection and revert into resistance during vancomycin therapy which is considered a new challenge. In a previous study, 2 of the isolated $S$. aureus strains from cow milk were vancomycin-resistant (Kou et al., 2021). Inconsistent with the present study, all of the previously isolated S. aureus strains from cheese and milk were sensitive to vancomycin (Castro et al., 2020; Giovanni et al., 2020).

In the current study, $48.4 \%$ of the isolated $S$. aureus strains were carriers for ermC gene. In case of erythromycin resistance S. aureus, $67(93.1 \%, 67 / 72)$ strains were carriers for ermC gene. However, 5 (6.9\%, 5/72) were not. Erythromycin-resistant $S$. aureus was also noticed in many previous research articles. For example, Antonios et al. (2015) reported $2.8 \%$ erythromycin-resistant S. aureus strains isolated from Greek ovine milk. Rola et al. (2015) reported $3.4 \%$ erythromycin-resistant $S$. aureus strains isolated from milk which was lower than that of the current investigation. Moreover, $27.4 \%$ of the isolated S. aureus strains from cheese samples showed resistance to erythromycin (Cai et al., 2021). Furthermore, $32.3 \%$ of the isolated S. aureus isolated from milk samples showed resistance to erythromycin (Kou 
et al., 2021) which was nearly similar to the current investigation. The phenotypic genotypic erythromycin resistance in $S$. aureus was also discussed in many previous research articles. For example, $7.9 \%$ of the isolated S. aureus strains from 2650 milk, cheese, and dairy product samples showed phenotypic erythromycin resistance profiles, while the ermC gene was detected in only $69.2 \%$ of these isolates (Jamali et al., 2015). Further, S. aureus isolated from sheep milk cheese were not carriers for ermC genes and were susceptible to erythromycin (Spanu et al., 2012). Previous studies have indicated that the methylase gene of macrolide ermC is responsible for erythromycin resistance among $S$. aureus isolates (Munita and Arias, 2016; Houri et al., 2020).

The statistical analysis of the current study revealed statistically significant results and so the alternative hypothesis that there is a significant association between each genotypic and its phenotypic features will be accepted. In other words, the presence of $m e c A$ gene in $S$. aureus was statistically associated with its encoding phenotypic resistance patterns against both penicillin and oxacillin. Moreover, along with an increase in the frequency of mecA gene, the resistance rates to both penicillin and oxacillin sharply increased. Previous studies indicated a perfect correlation between data obtained by conventional antimicrobial susceptibility patterns and PCR-based methods (Ray, 2017; Houri et al., 2020). Although there were 11 and 10 S. aureus strains in the current study which were phenotypically resistant to both penicillin and oxacillin respectively, they were mecA negative. The mecA-negative phenotypic-positive MRSA strains have been reported in many previous research articles. For example, 6 S. aureus strains (10.3\%) were identified as phenotypic MRSA although they were $m e c A$-negative (Zhang et al., 2016). The presence of $m e c A$-negative phenotypicpositive MRSA strains in bovine milk samples was also reported in China (Wang et al., 2014). In the current study, the presence of vanA and ermC genes in S. aureus was statistically associated with their encoding phenotypic antibiotic resistance patterns against vancomycin and erythromycin respectively. Furthermore, along with an increase in the frequency of vanA and ermC genes, there was a sharp increase in the resistance rates against vancomycin and erythromycin respectively. Although there were 8 and $9 S$. aureus strains in the current study which were genotypic positive for the vanA and erm $C$ genes respectively, they were phenotypic sensitive to vancomycin and erythromycin respectively. Spanu et al. (2012) previously reported that all the examined S. aureus strains did not carry vanA gene and were susceptible to vancomycin.

On the other hand, biofilm formation assay in the current study revealed that $6.8 \%$ of MRSA isolates exhibit weak biofilm-forming ability while the remaining 93.2\% exhibit no biofilm-forming ability. Notably, biofilms attached to organic and inorganic surfaces protect MRSA from antimicrobial agents, such as disinfectants or antibiotics. So, eradicating these biofilms becomes very problematic which will elevate the hazard of MRSA cross-contamination in dairy farms. Milk and dairy products contaminated with strong biofilm-forming MRSA can be considered additional risks in terms of food safety and public health hazards (Angelidis et al., 2020).

\section{CONCLUSION}

The presence of MDR S. aureus especially methicillin, vancomycin, and erythromycin-resistant $S$. aureus isolates in milk and dairy products poses a potential threat to public health and is of great concern in terms of animals' health. This presence highlights the need for continuous monitoring of hygiene in the dairy production chain. The presence of $m e c A$, $v a n A$, and ermC genes within the isolated $S$. aureus is statistically associated with their encoding phenotypic resistance patterns against both penicillin and oxacillin, vancomycin, and erythromycin respectively. Along with an increase in the frequency of mecA, vanA, and ermC genes, their phenotypic antibiotic resistance patterns sharply increased with OR $>1$. It is recommended to use PCR for continuous monitoring of genotypic resistance mecA, vanA, and erm $C$ genes in addition to studying their phenotypic resistance patterns in the cases associated with $S$. aureus infection as a routine monitoring in dairy farms. Reasonable restricted use of antimicrobials is recommended in dairy farms in addition to the application of biosecurity measures and hygienic husbandry practices.

\section{DECLARATIONS}

Shimaa Tawfeeq Omara proposed the idea, design, and coordination of the current study. She performed phenotypic and genotypic identification of the isolates, performed the statistical analysis, writing, and drafting of the manuscript. Ashraf Samir Hakim and Magdy Ali Bakry participated in the collection of samples and characterization of the isolates.

\section{Competing interests}

The authors have declared that they had no competing interests.

\section{Ethical consideration}

Ethical issue including plagiarism, consent to public misconduct, data fabrication and or falsification, double publication and or submission, redundancy has been checked by the authors.

\section{Authors' contribution}

All authors contributed equally to the present study. 
Angelidis AS, Komodromos D, Giannakou R, Arsenos G, Gelasakis AI, Kyritsi M, Filioussis G, Hadjichristodoulou C, Torounidou P, Papa A et al. (2020). Isolation and characterization of Staphylococcus aureus and methicillinresistant Staphylococcus aureus (MRSA) from milk of dairy goats under lowinput farm management in Greece. Veterinary Microbiology, 247: 108749. DOI: https://www.doi.org/10.1016/j.vetmic.2020.108749

Antonios Z, Theofilos P, Ioannis M, Georgios S, Georgios V, Evridiki B, Loukia E, Kyriaki M, Athanasios A, and Vasiliki L (2015). Prevalence, genetic diversity, and antimicrobial susceptibility profiles of Staphylococcus aureus isolated from bulk tank milkfrom Greek traditional ovine farms. Small Ruminant Research, 125: 120-126. DOI: https://www.doi.org/10.1016/j.smallrumres.2015.02.009

Beyene T, Hayishe H, Gizaw F, Beyi AF, Abunna F, Mammo B, Ayana D, Waktole H, and Abdi RD (2017). Prevalence and antimicrobial resistance profile of Staphylococcus in dairy farms, abattoir and humans in Addis Ababa, Ethiopia. BMC Research Notes, 10(1): 171. DOI: https://www.doi.org/10.1186/s13104-017-2487-y

Cai H, Kou X, Ji H, Wang X, Wang H, Zhang Y, Lu S, Li B, Dong J, Wang Q et al. (2021). Prevalence and characteristics of Staphylococcus aureus isolated from Kazak cheese in Xinjiang, China. Food Control, 123: 107759. DOI: https://www.doi.org/10.1016/j.foodcont.2020.107759

Campos-Peña E, Martín-Nuñez E, Pulido-Reyes G, Martín-Padrón J, Caro-Carrillo E, Donate-Correa J, Lorenzo-Castrillejo I, AlcobaFlórez J, Machín F, and Méndez-Alvarez S (2014). Multiplex PCR assay for identification of six different Staphylococcus spp. and Simultaneous detection of methicillin and mupirocin resistance. Journal of Clinical Microbiology, 52(7): 2698-2701. DOI: https://www.doi.org/10.1128/JCM.00918-14

Castro RD, Pedroso SHSP, Sandes SHC, Silva GO, Luiz KCM, Dias RS, Filho RAT, Figueiredo HCP, Santos SG, Nunes AC, and Souza MR (2020). Virulence factors and antimicrobial resistance of Staphylococcus aureus isolated from the production process of Minas artisanal cheese from the region of Campo das Vertentes, Brazil. Journal of Dairy Science, 103(3): 2098-2110. DOI: https://www.doi.org/10.3168/jds.2019-17138

Chajęcka-Wierzchowska W, Zadernowska A, Nalepa B, Sierpinska M, and Łaniewska-Trokenheim Ł (2015). Coagulase-negative Staphylococci (CoNS) isolated from ready-to-eat food of animal origin - Phenotypic and genotypic antibiotic resistance. Food Microbiology, 46: 222-226. DOI: https://www.doi.org/10.1016/j.fm.2014.08.001

Cheung GYC, Bae JS, and Otto M (2021). Pathogenicity and virulence of Staphylococcus aureus. Virulence, 12(1): 547-569. DOI: https://www.doi.org/10.1080/21505594.2021.1878688

Clinical and Laboratory Standards Institute (CLSI) (2013). Performance standards for antimicrobial susceptibility testing: Twentythird informational supplement M100-S23. CLSI, Wayne, PA, USA, 33: 1-199. DOI: https://www.doi.org/10.1016/s0196$\underline{4399(01) 88009-0}$

Frieri M, Kumar K, and Boutin A (2017). Antibiotic resistance. Journal of Infection and Public Health, 10(4): 369-378. https://doi.org/10.1016/j.jiph.2016.08.007

George SK, Suseela MR, El Safi S, Elnagi E, Al-Naam YA, Adam AAM, Jacob AM, Al-Maqati T, and Kumar KSH (2021). Molecular determination of van genes among clinical isolates of enterococci at a hospital setting. Saudi Journal of Biological Sciences, 28: 2895-2899. DOI: https://www.doi.org/10.1016/j.sjbs.2021.02.022

Giovanni N, Elisa S, Marta C, Rosa F, Loredana C, Alessandra B, and Antonio P (2020). Occurrence and characteristics of methicillin-resistant Staphylococcus aureus (MRSA) in buffalo bulk tank milk and the farm workers in Italy. Food Microbiology, 91: 103509. DOI: https://www.doi.org/10.1016/j.fm.2020.103509

Houri H, Samadpanah M, Tayebi Z, Norouzzadeh R, Malekabad ES, and Dadashi A (2020). Investigating the toxin profiles and clinically relevant antibiotic resistance genes among Staphylococcus aureus isolates using multiplex-PCR assay in Tehran, Iran. Gene Reports, 19: 100660. DOI: https://www.doi.org/10.1016/j.genrep.2020.100660

Jamali H, Paydar M, Radmehr B, Ismail S, and Dadrasnia A (2015). Prevalence and antimicrobial resistance of Staphylococcus aureus isolated from raw milk and dairy products. Food Control, 54: 383-388. DOI: https://www.doi.org/10.1016/j.foodcont.2015.02.013

Kou X, Cai H, Huang S, Ni Y, Luo B, Qian H, Ji H, and Wang X (2021). Prevalence and characteristics of Staphylococcus aureus isolated from retail raw milk in Northern Xinjiang, China. Frontiers in Microbiology, 12: 705947. DOI: https://www.doi.org/10.3389/fmicb.705947

Munita JM, and Arias CA (2016). Mechanisms of antibiotic resistance. Microbiology Spectrum, 4(2): 10. DOI: https://www.doi.org/10.1128/microbiolspec.VMBF-0016-2015

Omara ST, Syame SM, and Elgabry EA (2016). Molecular detection of the clumping factor (fibrinogen receptor) in the Enterotoxigenic S. aureus isolated from Raw Milk and Traditional Cheese. International Journal of ChemTech Research, 9(12): 923-933. Available at: https://sphinxsai.com/2016/ch_vol9_no12/2/(923-933)V9N12CT.pdf

Panchal VV, Griffiths C, Mosaei H, Bilyk B, Sutton JAF, Carnell OT, Hornby DP, Green J, Hobbs JK, Kelley WL et al. (2020). Evolving MRSA: High-level $\beta$-lactam resistance in Staphylococcus aureus is associated with RNA polymerase alterations and fine tuning of gene expression. PLoS Pathogrns,16(7): e1008672. DOI: https://www.doi.org/10.1371/journal.ppat.1008672

Ray S, Das S, and Suar M (2017). Molecular mechanism of drug resistance. In: Arora G., Sajid A., Kalia V. (eds) drug resistance in bacteria, Fungi, Malaria, and Cancer. Springer, Cham, pp. 47-110. DOI: https://www.doi.org/10.1007/978-3319-48683-3_3

Rola JG, Sosnowski M, Ostrowska M, and Osek J (2015). Prevalence and antimicrobial resistance of coagulase-positive Staphylococci isolated from raw goat milk. Small Ruminant Research, 123: 124-128. DOI: https://www.doi.org/10.1016/j.smallrumres.2014.11.010 
Regasa S, Mengistu S, and Abraha A (2019). Milk safety assessment, isolation, and antimicrobial susceptibility profile of Staphylococcus aureus in selected dairy farms of mukaturi and Sululta Town, Oromia Region, Ethiopia. Veterinary Medicine International, Article ID: 3063185. DOI: https://www.doi.org/10.1155/2019/3063185

Schlegelova J, Vlkova H, Babak V, Holasova M, Jaglic Z, Stosova T, and Sauer P (2008). Resistance to erythromycin of Staphylococcus spp. isolates from the food chain. Veterinární Medicína, 53(6): 307-314. DOI: https://www.doi.org/10.17221/1856-vetmed

Spanu V, Spanu C, Virdis S, Cossu F, Scarano C, and De Santis EP (2012). Virulence factors and genetic variability of Staphylococcus aureus strains isolated from raw sheep's milk cheese. International Journal of Food Microbiology, 153: 53-57. DOI: https://www.doi.org/10.1016/j.ijfoodmicro.2011.10.015

Wang L, Yu F, Yang L, Li Q, Zhang X, Zeng Y, and Xu Y (2010). Prevalence of virulence genes and biofilm formation among Staphylococcus aureus clinical isolates associated with lower respiratory infection. African Journal of Microbiology Research, 4 (23): 2566-2569. DOI: https://www.doi.org/10.5897/AJMR.9000589

Wang X, Wang X, Wang Y, Guo G, Usman T, Hao D, Tang X, Zhang Y, and Yu Y (2014). Antimicrobial resistance and toxin gene profiles of Staphylococcus aureus strains from Holstein milk. Letters in Applied Microbiology, 58: 527-534. DOI: https://www.doi.org/10.1111/lam.12221

Zayda MG, Masuda Y, Hammad AM, Honjoh K, Elbagory AM, and Miyamoto T (2020). Molecular characterisation of methicillinresistant (MRSA) and methicillin-susceptible (MSSA) Staphylococcus aureus isolated from bovine subclinical mastitis and Egyptian raw milk cheese. International Dairy Journal, 104: 104646. DOI: https://www.doi.org/10.1016/j.idairyj.2020.104646

Zhang L, Li Y, Bao H, Wei R, Zhou Y, Zhang H, and Wang R (2016). Population structure and antimicrobial profile of Staphylococcus aureus strains associated with bovine mastitis in China. Microbial Pathogenesis, 97: 103-109. DOI: https://www.doi.org/10.1016/i.micpath.2016.06.005 